\title{
Research on the Professionalization Development of Ideological and Political Theory Teachers in Colleges
}

\author{
Jie $\mathrm{HE}^{1, \mathrm{a}}$ \\ ${ }^{1}$ Tianjin Vocational Institute, Tianjin 300410, China \\ ahejie1965@126.com
}

\begin{abstract}
Keywords: College teachers. Ideological and political teachers. Professionalization of teachers. Professionalization development of teachers
\end{abstract}

\begin{abstract}
The professionalization development of ideological and political teachers in colleges is the premise and foundation for building a high quality professional ideological and political teaching team. In recent years, some scholars have discussed and studied the professionalization of college teachers and the professionalization development of ideological and political teachers in universities from different perspectives, and have put forward their own point of view. They mainly focused on the connotation, characteristics, difficulties and countermeasures of the professionalization development of college teachers, and the main problems and development strategies of the professionalization development of ideological and political teachers in universities.
\end{abstract}

\section{Introduction}

China's ideological and political theory course (also called "Ideological and Political Course") is the main channel to cultivate college students' life concept, values and world view. It bears the important responsibility and mission of using the theory of socialism with Chinese characteristics to arm the minds of college students, promote the construction of the socialist core value system and train high-quality talents. The key to improving the quality and level of ideological and political education in colleges is the teacher. Improving the overall quality of ideological and political teachers in colleges and universities is the fundamental measure to enhance the effectiveness of ideological and political courses. The key to the construction of teaching staff is to set up a platform for teachers' growth and development, and continuously improve the professionalism of ideological and political teachers. This article attempts to sort out the research on the professionalization development of ideological and political teachers in colleges from the aspects of the connotation and characteristics of college teachers' professionalization, the difficulties and countermeasures they face, and the major problems and development strategies of the professionalization development of college ideological and political teachers.

\section{Some Basic Problems in the Development of College Teachers' Professionalization}

Connotation and Characteristics of College Teachers' Specialization. Before analyzing the connotation of the professionalization of college teachers, it is necessary to clarify two concepts. Profession - it refers to special professions, which means that people with special specialized knowledge and technology after special education or training, to solve the problems of life and society in accordance with professional standards, and to obtain remuneration and social status. This is a concept in modern sociology. Professionalization -it refers to the specialization of groups or individuals. It requires practitioners to have well-recognized theory and related research, have a college degree or above, obtain professional qualifications, acquire specific skills, and continuously improve their knowledge and skills during their careers. This shows that professionalization is an upgrade and standardization of profession, is a significant sign of sublimation in a profession, and a dynamic process in which the practitioners' knowledge, skills, and social status spiral upward ${ }^{[1]}$. Teacher professionalization is mainly for the whole teacher team. It is a consensus, a standard and a career. Teacher specialization refers to the professional growth process of teachers throughout their professional careers through lifelong professional training, acquisition of professional knowledge and 
skills in education, implementation of professional autonomy, performance of professional ethics, and gradual improvement of their self-educational qualities.

At present, China has corresponding practitioners from preschool education, basic education, higher education, and adult education. The profession has formed a complete system. There are three characteristics of the professionalization of college teachers: having more advanced knowledge; having more freedom and more time in academic exploration; having greater flexibility in educating. Observing from the perspective of sociology, the professionalization of college teachers is a dynamic development process integrating sociality, academics, education and creativity. "Sociality" means that college teachers need to enter the society, advance with the times, pay close attention to the political, economic, cultural and technological development trends, and incorporate them into the talent training program and teach them to the students. "Academics" means the subject knowledge and skills that college teachers should have, and the ability to solve practical problems using them. "Education" means college teachers should integrate professional knowledge and professional skills with teaching in their activities. "Creativity" means that college teachers should make innovations in knowledge, technology, methods and contents in teaching and scientific research to achieve innovative results and promote social progress. Professor Xiaoyong Mu's team examines the professionalization of college teachers from culture, life philosophy and personality psychology. Liu Yanmei analyzes the connotation of the professionalization of college teachers from the perspective of culture and proposes three unifications: (1)College Teachers' Attributes: the unification of professionalism and academics; (2)The nature of college teachers' professionalization: the unification of subject specialization and education specialization; (3)The process of professionalization of college teachers: the unification of development stage and goal level. The comprehensive, scientific, and in-depth investigation and research from multiple perspectives can make the theory of college teacher professionalization more colorful.

Difficulties and Countermeasures in College Teachers' Professionalization Development. The development of teacher professionalization is mainly for individual teachers. It is a pursuit of value, a goal, and a process of teachers' self-development and self-transcendence from immature to maturity. The development of college teachers' professionalization is their professional growth process. To become excellent college teachers, they should take life-long professional training, comply with professional ethics, establish professional beliefs, implement professional autonomy, master professional skills, acquire professional knowledge, and improve professional qualities. In recent years, our government has increased education investment, so that the hardware environment of colleges have obviously improved. Strengthening the connotation construction is urgently needed. The most important of them is the construction of the teacher team, and the development of teacher professionalization is the key. In fact, however, many teachers have some "professional confusion". In response, many scholars have conducted in-depth research and discussion and have proposed some countermeasures to improve the situation. Due to the different circumstances of different colleges, scholars have different perspectives and different methods of research, so the problems found and measures for improvement are not the same. Some typical research results are listed here for reference.

Professor Zaisheng Zhang's team [2] has investigated the current situation of teachers' professionalization in colleges in China. The main problems they found include: pre--employment evaluation system is not perfect; pre and post-employment training have no rules; the conflict between scientific research and teaching; Poor professional practice and research capacity affect the quality of teaching; scientific research ability and level can not meet the needs; high pressure leads to weak sense of responsibility and work enthusiasm; neglecting the necessary humanistic education for students. Professor Zhang's team constructed the maturity model of college teachers' professionalization from the perspectives of social maturity, management maturity, and implementation maturity, and put forward the countermeasures to improve the professionalization of college teachers from the aspects of teachers' personal ability cultivation, college internal management and national policies, etc. They include: (1)Teachers must personally improve their quality. Teachers should not only impart knowledge, but also shoulder the responsibility of 
cultivating the students' noble ideology and morality, as well as their strong will and faith. Therefore, college teachers must have excellent quality and ability. (2)Schools need to strengthen training and management. For example: performance evaluation, recruitment management, lifelong training, etc. (3)The country needs to establish and improve relevant policy support. To enhance teachers' sense of professional accomplishment, economic satisfaction, status honor and job security. (4)To construct an index system for the professionalization maturity of college teachers.

Researcher Jian Lin's team [3] thinks that: when the science and technology are rapidly developing, as the college teachers who are training high-level talents, they bear the burden of knowledge and technological innovation. So they should walk in the forefront of teachers' professionalization and keep up with the development of the times. However, at present, the professionalization development of college teachers in China is lagging behind the requirements of the times and is facing a series of difficulties. They include: assessment, the contradiction between teaching evaluation and scientific research evaluation; employment, the contradiction between education and academics; training and development, the contradiction between improving the academic level and improving the teaching quality; professional ethics, the contradiction between imparting knowledge and cultivating character. Researcher Jian Lin's team considers the improvement of college teachers' professionalization development as a systematic project, and puts forward the path to build professionalization development of college teachers from three levels. They include: institutional aspect - to increase institutional innovation and build aninstitutional system of professionalization development of college teachers; school aspect -colleges should establish a perfect recruitment management system, establish a multi-evaluation subject and a scientific performance evaluation system, and create a teacher culture that suits the professionalization development of teachers; teacher aspect -to strengthen the sense of responsibility and internal motivation, strive to be an innovative teacher, learning teacher, investigative teacher, and double-education teacher.

The research results of some scholars [4-5] have raised similar problems and countermeasures as mentioned above. They have also raised some other problems. They include: college teachers' professional autonomy is inconsistent; college teacher organizations are weak; college teachers have low innovation ability; the professional ethics of some college teachers need to be strengthened; some college teachers have low scientific research ability and their teaching results are not satisfactory, etc. Those scholars have put forward many solutions for these problems. Some other scholars have studied the professionalization of college teachers from different perspectives, such as: sustainable development[6]; introspection [7];local colleges, etc. These research achievements are worthy of reference.

\section{Research Status of Professionalization Development of Ideological and Political Teachers in Colleges}

Connotation and Characteristics of Professionalization Development of Ideological and Political Teachers in Colleges. The professionalization development of ideological and political teachers in colleges is their professional growth process. To become excellent college ideological and political teachers, they should take life-long professional training, comply with professional ethics, establish professional beliefs, implement professional autonomy, master professional skills, acquire professional knowledge, and improve professional qualities. It is a dynamic and evolving process. It includes educational development - ideology and politics teachers should master the basic laws of college students' physical and mental development and the basic law of ideological and political education. It also includes the development of discipline -ideological and political teachers should have rich theoretical knowledge of Marx theory. At the same time, the professionalization development of ideological and political teachers in colleges is a dynamic system that enriches and develops with the development of society and teaching practice. Ideological and political teachers in colleges are shouldering important responsibilities and special missions. Their professionalization development has 5 characteristics.

a) The strong belief of the teachers. It means the teachers' persistent pursuit of communist ideals and beliefs and their high recognition of Marx's theory. In the high level of professionalization 
development of ideological and political teachers, the teachers should have higher level of politics and policy and strong political acumen and discernment.

b) The realization of teachers' professional autonomy. Professional autonomy means that, in teaching practice, teachers independently determine their implementation strategies and behavior standards according to their professional knowledge, teaching objectives and teaching tasks. The realization of professional autonomy is an important index to measure the professionalization level of ideological and political teachers in colleges, and it's also the key to improving their professional status. Therefore, the professional autonomy of ideological and political teachers in colleges should be fully demonstrated, including the right to choose teaching methods and content of education, education reform and autonomy in scientific research.

c) The integration of teacher expertise. The ideological and political teachers in colleges should achieve the following points: (1)Deep understanding of their expertise. (2)Mastering psychology and pedagogy. (3)Mastering the knowledge of disciplines, cultural sciences and education. (4)Summing up practical knowledge. Through teaching practice, teachers should sum up experience, profoundly reflect themselves, raise awareness, and guide education. Education knowledge, subject knowledge, and related knowledge must be integrated through teaching and education practices and eventually translated into teachers' own professional knowledge.

d) The improvement of teachers' professional qualities. The professional qualities are concentrated reflection of teachers' professionalism, work attitude, external appearance, and professional ethics in the professional process. In the new situation, the professional qualities of ideological and political teachers need to be further improved.

e) Mastery of teachers' professional skills. The professional skills include: (1)The ability to use the modern technologies. The ideological and political teachers should skillfully use modern information technology to improve teaching methods. (2)The ability to develop curriculum resources. One of the important symbols of the creativeness of ideological and political teachers is to effectively develop and use curriculum resources and enhance the timeliness of education. (3)The ability to conduct educational scientific research. Ideological and political teachers should actively participate in the study of disciplines, so that they can change from "experienced" teachers to "researching" teachers in order to improve their academic level and accelerate their professional development.

Main Problems in Professionalization Development of Ideological and Political Teachers in Colleges. Since the reform and opening up, the education and teaching reforms in higher education institutions in China have continuously increased. The professionalization development of ideological and political teachers has made great progress and accumulated some experience. However, there are still some practical problems in it. It can not satisfy the requirements and expectations of the party, the country and the people for the ideological and political courses in colleges. Therefore, in-depth analysis of the current situation and deep digging of the problems of the development, and actively taking measures to deal with and solve them are of great practical significance to further promote the reform and innovation of ideological and political education in colleges. Due to the different situations of universities, the perspectives of scholars and the methods of research are different, so that the problems and improvement measures are different. Here are some typical research results.

According to Guohao Ding's research[8], the following problems exist in the professionalization development of ideological and political teachers in colleges: the political beliefs of ideological teachers need to be further strengthened. The ideological and political teachers' Marxist theoretical foundation needs to be further solid. Their awareness of educating people needs to be further strengthened. Their characteristics of humanistic care need to be further developed. Their innovation ability needs further improvement. At the same time, Ding puts forward the discipline support to strengthen the professionalization development of ideological and political teachers in colleges, strengthen the institutional guarantee and standardized construction, and strengthen measures of training for ideological and political teachers.

The research of Lirong Zhang's team[9] shows that: the current professionalization development of ideological and political teachers in colleges is facing some "special confusions". Many teachers 
have asked the following questions: In the education and teaching process, should we focus on subject ownership or emphasis on career development? Should we pay more attention to scientific research or more emphasis on teaching students? Should we pay more attention to the salary or the conscience? After an in-depth analysis on the causes of confusions, they got the conclusion: firstly, we must change the traditional concepts and optimize the assessment system; secondly, we should improve the system and strengthen the professional training of ideological and political teachers; thirdly, we should strengthen teaching and academic research and constantly improve the quality and level of teaching. By doing these, we can speed up professionalization development of ideological and political teachers and improve the overall quality of teachers.

Other scholars have studied the professionalization development of ideological and political teachers from different perspectives and methods: questionnaires, school-based training environment[10], and perspective from non-ideological and political disciplinary background. These research achievements are worthy of reference.

Implementation Strategy of Professionalization Development of Ideological and Political Teachers in Colleges. a) Macro level: national policy orientation, optimizing professional environment. (1)The competent departments should actively build a platform for the development of ideological and political teachers in colleges, so that they can develop in multiple channels and serve the society. (2)Propaganda department should strengthen propaganda of ideological and political education in colleges. They must vigorously publicize the important role of ideological and political education in the cultivation of talents in colleges, and stimulate the potential energy and enthusiasm of the professionalization development of ideological and political teachers in colleges. In the process of realizing the great rejuvenation of the Chinese nation, the creativity and value of ideological and political teachers are irreplaceable. (3)The administrative departments must improve relevant laws and regulations and create an excellent environment for national support, public recognition, and social trust. Under the influence of professional honor, pride and sense of belonging, the ideological and political teachers in colleges will truly regard the teaching and research of ideological and political courses as a promising profession and career.

b) Meso level: colleges need scientific management and professional status promotion. (1)Colleges should pay attention to professionalization development of ideological and political teachers. They must seriously grasp the key issues and financial investment in the construction of ideological and political education, really improve the living working conditions of ideological and political teachers, and fully demonstrate the professional status of ideological and political teachers. (2)Colleges and universities should set up a professional community of ideological and political teachers that use colleges and universities as their bases, in the form of mutual discussion, and use education as their carrier. It can further promote the development of ideological and political teachers' professional knowledge skills. (3)Scientifically plan and manage ideological and political teaching and research. We should clear our goals, plan the reasonable preparation of personnel, institutions, and funds in teaching reform, discipline planning, and scientific research, combine administrative power and academic power, clear responsibilities, powers and interests, and improve work efficiency and quality.

c) Micro level: teachers should be active and build professional ladder. (1)Ideological and political teachers should strengthen the research of education science. The more advanced to the professionalization development of teachers, the more attention should be paid to scientific research: study the essence of Marxist theory; study on the issue of socialist construction with Chinese characteristics; study on Ideological and political education of college students in the new situation. (2)Ideological and political teachers should form a sense of reflection. They should constantly reflect on their teaching behavior, research process and way of doing things. The essence of reflection is to dare to break through, to doubt, to surpass, and move towards higher level. (3)Ideological and political teachers should strengthen their lifelong learning. The professionalization development of ideological and political teachers is a dynamic process that is constantly improving in teaching practice. They should constantly increase the "length, width and height" of knowledge and skills, so that they can achieve the growth of "experiential, scholarly and expert" teachers. 
The professionalization development of ideological and political teachers in colleges is the foundation for building a highly qualified and professional ideological and political teacher team. By further studying and answering the questions of the professionalization development of ideological and political teachers under the new situation, we can promote the construction of ideological and political teachers in colleges, improve the teaching level of ideological and political courses, and strengthen and improve the propaganda and ideological work in colleges under the new situation. In the practice of realizing the great rejuvenation of the Chinese nation and building socialism with Chinese characteristics, only by strengthening the professionalization development and improving the overall quality of them, the ideological and political teachers can shoulder the glorious duty of training outstanding talents for the great rejuvenation of the Chinese nation.

\section{Acknowledgements}

This work was financially supported by the "Thirteenth Five" planning project of Tianjin Education Science (Project number: VE3327) ; the Tianjin 2015 philosophy and social science planning project (project Number: TJJX15-030); the 2016 ministry of education's demonstration of Marxist college and outstanding teaching and research team construction projects (Project number: 16JDSZK042).

\section{References}

[1] Hoberman S, Mailick S. Professional Education in the United States: Experiential Learning, Issues, and Prospects (Westport, Connecticut: Praeger Publishers, America 1994).

[2] Z.H. Zhang, C.Y. Zhang. Journal of Tianjin Normal University (social science block), 2010, No.4, p.73. (In Chinese)

[3] J. Lin, X.Q. Lin. Journal of Zhangzhou Normal University (philosophy and social science block), 2013, No.2, p.131. (In Chinese)

[4] D. Xin. Education and Profession, 2014, No.9, p.77. (In Chinese)

[5] D. Yao, H.L. Wang. Journal of Liaoning University of Technology (social science block), 2013, No.5, p.65. (In Chinese)

[6] Y.G. You. Journal of Chifeng University (social science block), 2013, No.11, p.170. (In Chinese)

[7] X.X. Wen, X.W. Wen. Research on Continuing Education, 2014 ,No.4, p.66. (In Chinese)

[8] G.H. Ding. Journal of Qilu Normal University, 2013, No.2, p.27. (In Chinese)

[9] L.R. Zhang, Y.P. Liu. Education and Profession, 2012, No.8, p.79. (In Chinese)

[10] W.F. Education and Profession, 2014, No.1, p.76. (In Chinese) 